\title{
Therapeutic management of odontogenic abscess in maxillofacial area in patient confirmed covid-19: A case report and literatur review
}

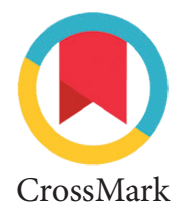

Andi Tajrin*

\section{Abstract}

Objective: The purpose of writing this case report and literature review is to discuss the management of therapy in covid-19 patient with odontogenic abscess in the maxillofacial area.

Method: A 65-year-old male patient came to the Ibnu Sina Makassar Hospital, complaining of swelling of the right submandibular blood extending to the buccal, sublingual, submental, and temporal. Patient was in a limp condition, shortness of breath (dyspnea), coughing, difficulty opening his mouth, difficulty eating and swallowing with pulse 121 times / minute, breathing 32 times / minute, and oxygen saturation of $94 \%$ (simple mask of $5 \mathrm{lpm}$ ). Patient was diagnosed with the right submandibular abscess extending to the right buccal, right temporal, right and left sublingual, and submental with sepsis due to gangrene of tooth root 46 . Surgical incision and drainage of the abscess was performed under general anesthesia.

Results: Incision and drainage of the abscess in the patient was carried out even with the suspicion that the patient was indicated as having been exposed to covid-19 by following the principle of preventing covid-19 infection.

Conclusion: Surgical preparation, appropriate therapeutic management, and proper use of PPE will help provide the best service to patients while protecting medical personnel in the current Covid-19 pandemic era.
Department of Oral Maxillofacial and Surgery, Faculty of Dentistry, Hasanuddin University, Makassar, Indonesia

*Correspondence to: Andi Tajrin, Department of Oral Maxillofacial and Surgery, Faculty of Dentistry, Hasanuddin University, Makassar, Indonesia

tajrinumi@gmail.com

Received: 1 January 2021

Revised: 25 February 2021

Accepted: 30 March 2021

Available Online: 1 April 2021

Keywords: Covid- 19, Odontogenic abscess, Pandemic, Therapy

Cite this Article: Tajrin A. 2021. Therapeutic management of odontogenic abscess in maxillofacial area in patient confirmed covid-19: A case report and literatur review. Journal of Dentomaxillofacial Science 6(1): 70-74. D0l: 10.15562/jdmfs.v6i1.1182

\section{Introduction}

Infection of the maxillofacial region is a lifethreatening disease that is generally caused by odontogenic infections. ${ }^{1}$ Infections involving the maxillofacial region have spaces that are anatomically connected to each other that then allows infection to spread to vital organs leading to various complications. ${ }^{2}$ Difficulty breathing (dyspnea), difficulty swallowing (dysphagia) and immensely fast spreading infections require immediate treatment because they can pose a direct threat to the respiratory tract, the need for an incision and drainage may be necessary to be immediately performed. $^{3}$

Since the Covid-19 pandemic broke out, Medical Personnel must organize patient treatment in such a way to minimize transmission of the infection, and all relevant treatment options must be available to provide adequate patient treatment. ${ }^{4}$ Surgical preparation strategies will help provide the best possible treatment for patient while protecting the medical personnel. ${ }^{5}$ The concept must be developed by considering the possible needs of the patient according to the urgency of treatment. ${ }^{4}$

The preoperative evaluation is the first step to ascertain whether the surgical care needs to be carried out. ${ }^{6}$ the precautionary principles are then concerned which are simplifying the operation and trying to avoid complicated surgical techniques to reduce operation time. The longer the intervention time, the greater the risk of potential infection for medical staffs and paramedics. ${ }^{7}$ Personal protective equipment (PPE) for the medical team is essentially important in preventing transmission of the virus, the use of personal protective equipment must be adequately selected and used appropriately. ${ }^{8}$ The operating room can be a high-risk area for transmission of infection to and from sufferers. ${ }^{4,9}$ Operating rooms with negative pressure environments are ideal for reducing the spread of the virus. ${ }^{4,10}$

In several countries have reported the management of preparation for surgery, using of PPE, and preparation of the operating room in patients with confirmed COVID-19. Table 1..$^{7,11-14}$

The purpose of this case report and literatur review is to discuss the management of therapy in covid-19 patient with odontogenic abscess in the maxillofacial area.

\section{Case Report}

A 65-year-old man came to the Ibnu Sina Makassar Hospital, complaining of swelling in the right cheek area, difficulty opening his mouth and swallowing, 
Table 1 A review of the literature of several countries on procedures for preparation for operations during the Covid-19 pandemic

\begin{tabular}{|c|c|c|c|c|c|c|}
\hline \multirow[b]{2}{*}{ Authors } & \multirow[b]{2}{*}{ Country } & \multicolumn{3}{|c|}{ Preoperatif } & \multirow[b]{2}{*}{$\begin{array}{l}\text { Preparation of the } \\
\text { Operating Room }\end{array}$} & \multirow[b]{2}{*}{ PPE } \\
\hline & & Anamnesis & $\begin{array}{l}\text { Physical } \\
\text { examination }\end{array}$ & $\begin{array}{l}\text { Supporting } \\
\text { Examination } \\
\text { / Covid-19 } \\
\text { Examination }\end{array}$ & & \\
\hline $\begin{array}{l}\text { Sohal et all, } \\
2020\end{array}$ & Tanzania & $\begin{array}{l}\text { - There is a history of fever, } \\
\text { cough and shortness } \\
\text { - History of travelling from } \\
\text { out of town }\end{array}$ & $\begin{array}{l}\text { Body } \\
\text { temperature }\end{array}$ & $\begin{array}{l}\text { Thoraks } \\
\text { Konvensional }\end{array}$ & Negative pressure & $\begin{array}{l}\text { PPE Level } 3 \text { (Cannot } \\
\text { be postponed and / or } \\
\text { confirmed positive) } \\
\text { PPE Level } 2 \text { (confirmed } \\
\text { negative) }\end{array}$ \\
\hline $\begin{array}{l}\text { Jiang and } \\
\mathrm{Ma}, 2020\end{array}$ & China & $\begin{array}{l}\text { - There is a history of fever, } \\
\text { cough and shortness } \\
\text { - History of travelling from } \\
\text { out of town }\end{array}$ & $\begin{array}{l}\text { Body } \\
\text { temperature }\end{array}$ & CT Thoraks & Negative pressure & $\begin{array}{l}\text { PPE Level } 3 \text { (Cannot } \\
\text { be postponed and / or } \\
\text { confirmed positive) } \\
\text { PPE Level } 2 \text { (confirmed } \\
\text { negative) }\end{array}$ \\
\hline $\begin{array}{l}\text { Panesar } \\
\text { et all, } 2020\end{array}$ & $\begin{array}{l}\text { United } \\
\text { States of } \\
\text { America }\end{array}$ & $\begin{array}{l}\text { - There is a history of fever, } \\
\text { cough and shortness } \\
\text { - History of travelling from } \\
\text { out of town }\end{array}$ & $\begin{array}{l}\text { Body } \\
\text { temperature }\end{array}$ & $\begin{array}{l}\text { RT-PCR (Elective) } \\
\text { Rapid Test } \\
\text { (Emergency) }\end{array}$ & Negative pressure & $\begin{array}{l}\text { PPE Level } 3 \text { (Cannot } \\
\text { be postponed and / or } \\
\text { confirmed positive) } \\
\text { PPE Level } 2 \text { (confirmed } \\
\text { negative) }\end{array}$ \\
\hline $\begin{array}{l}\text { R. Coimbra } \\
\text { et all. } 2020\end{array}$ & $\begin{array}{l}\text { European } \\
\text { Society }\end{array}$ & $\begin{array}{l}\text { - There is a history of fever, } \\
\text { cough and shortness } \\
\text { - History of travelling from } \\
\text { out of town }\end{array}$ & $\begin{array}{l}\text { Body } \\
\text { temperature }\end{array}$ & $\begin{array}{l}\text { RT-PCR(Elective) } \\
\text { CT-Thoraks } \\
\text { (Emergency) }\end{array}$ & Negative pressure & $\begin{array}{l}\text { PPE Level } 3 \text { (Cannot } \\
\text { be postponed and / or } \\
\text { confirmed positive) } \\
\text { PPE Level } 2 \text { (confirmed } \\
\text { negative) }\end{array}$ \\
\hline $\begin{array}{l}\text { I. Barca } \\
\text { et all. } 2020\end{array}$ & Italia & $\begin{array}{l}\text { - There is a history of fever, } \\
\text { cough and shortness } \\
\text { - History of travelling from } \\
\text { out of town }\end{array}$ & $\begin{array}{l}\text { Body } \\
\text { temperature } \\
\text { Saturasi } \\
\text { Oksigen }\end{array}$ & RT-PCR & Negative pressure & $\begin{array}{l}\text { PPE Level } 3 \text { (Cannot } \\
\text { be postponed and / or } \\
\text { confirmed positive) } \\
\text { PPE Level } 2 \text { (confirmed } \\
\text { negative) }\end{array}$ \\
\hline
\end{tabular}

which had been felt since about 11 days before entering the hospital. Previously, the patient was treated at the regional hospital for about one week with the administration of metronidazole, B Com, Zink, vitamin C, and NGT placement because the patient had difficulty eating. The patient had a history of hypertension but was under control and had had a stroke about five years ago.

Patient was screened early for Covid-19, looking at clinical symptoms, vital signs, physical examination, lab examination, chest X-ray, and rapid antibody examination. Patient was found having cough, tachycardia (121 times / minute) and tachypnea (32 times / minute), and under a condition of dyspnea with Sat O2 94\% (simple mask $5 \mathrm{lpm}$ ). Chest X-ray with the impression of a bronchovascular pattern, did not appear to be a specific active process as an indication of the presence of bronchitis. Meanwhile, the results of the rapid antibody test showed that it was not reactive while the results of routine blood tests showed leucocytes above the normal limit of 12.8103 / $\mu \mathrm{L}$, hemoglobin, hematocrit, and erythrocytes below normal limits, which then hypernatremia and hyperglycemia.
By looking at vital signs, clinical symptoms, and laboratory examinations, the patient was indicated to have been exposed to the Covid-19, thus the Sars Cov-2 virological test still needed to be carried out using the PCR method to confirm the condition. The result came out the day after examination and showed that the patient was confirmed positive Covid-19.

On the examination, the patient was found to be conscious, weak, moderate dehydrated, dysphagia, and trismus (opening mouth $\pm 14 \mathrm{~mm}$ ). The patient appears to have facial asymmetry accompanied by pain. Swelling in the right buccal area extending to the temporal, submandibular and submental areas with a size of $\pm 26 \mathrm{~cm} \times 10.5 \mathrm{~cm} \times 3.5 \mathrm{~cm}$, hard consistency in the right temporal, right buccal and submental, soft consistency of the right submandibular, redness and warmth of the surrounding tissue figure 1.

Despite the difficulty in carrying out the intraoral examination due to trismus, the source of infection was identified as being associated with the remaining root of the lower right first molar (tooth 46), with drainage of pus in the area of the tooth and a 


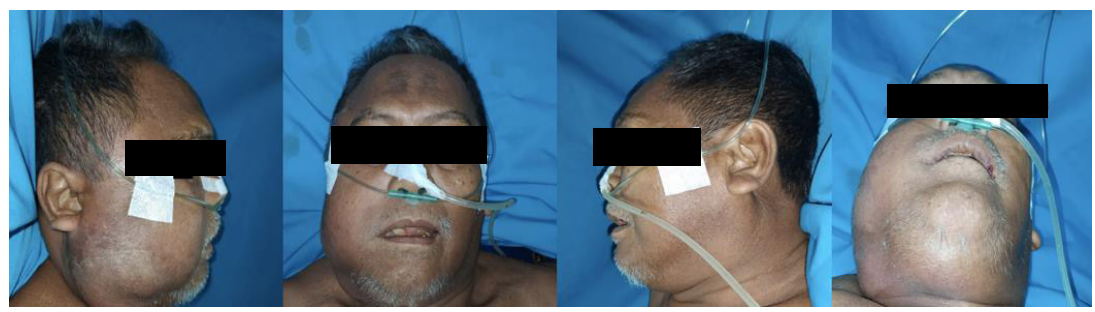

Figure 1 Extraoral clinical features

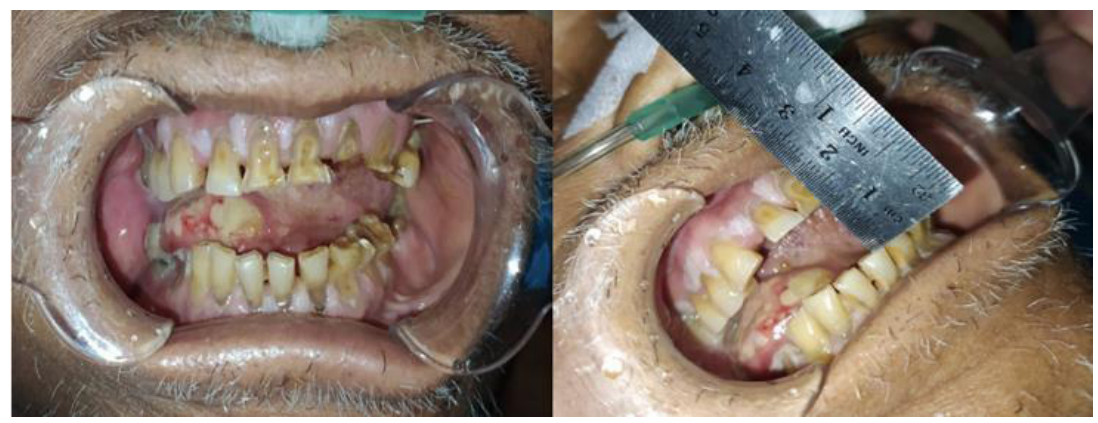

Figure 2 Intraoral clinical features and mouth opening

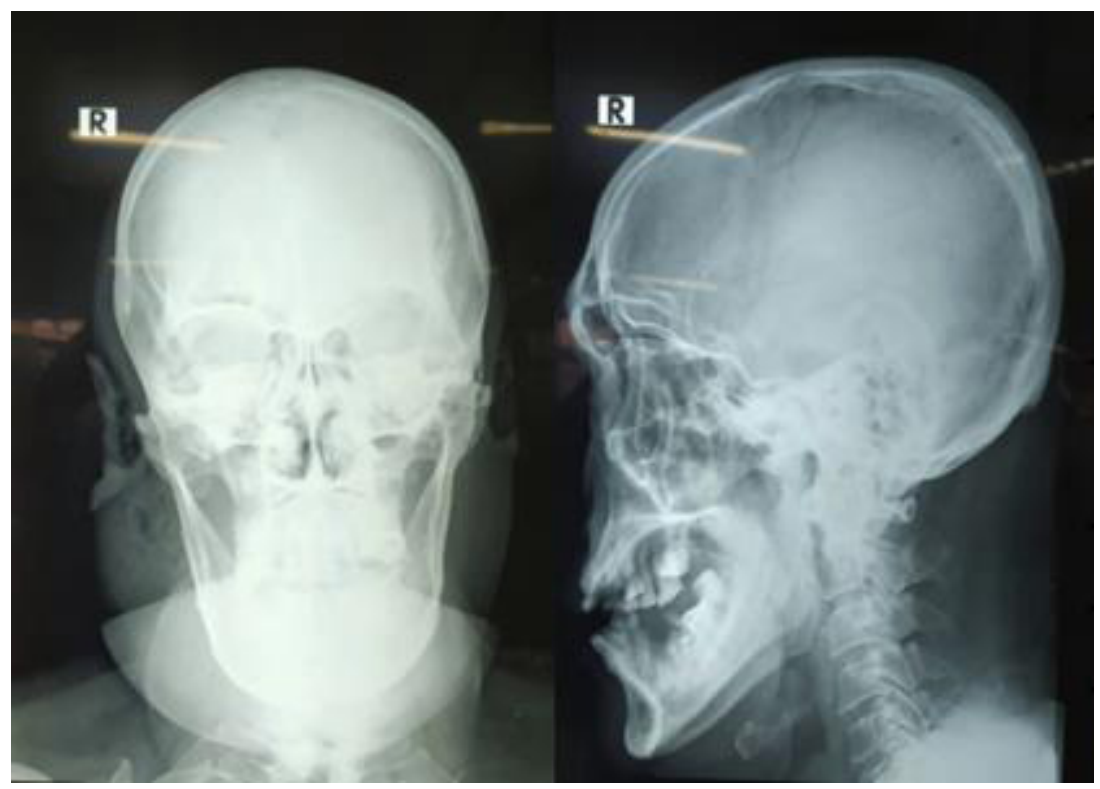

Figure 3 Ap-Lat Cervical Radiograph

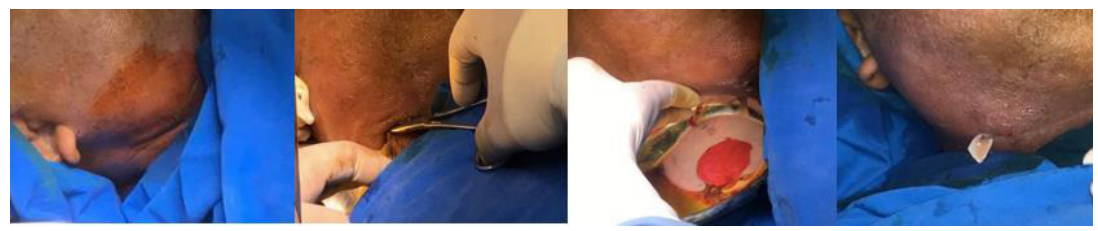

Figure 4 Incision and drainage of the abscess

raised tongue indicating that the abscess extends to the sublingual blood figure 2 .

On the Ap-Lat cervical radiograph figure 3, it shows a soft tissue mass in the right mandibular region that did not interfere the bone. Cervical spine was in good condition, no visible fracture, good bone mineralization, and spinal discs was in normal limits. Therefore, it can be concluded that the soft tissue in the right mandibular region does not deconstruct the bone.

The patient was diagnosed with the right submandibular abscess extending to the right buccal, right temporal, right and left sublingual, and submental with sepsis due to gangrene of root tooth 46 . The first treatment was carried out by taking samples for microbiological examination tests, giving oxygen with a simple face mask of 5 lpm, IVFD RL 30 tpm, empirical antibiotic administrating Ceftriaxone of inj 1gr/12 hours/IV, Metronidazole Drips 500 mg/8 hours/IV, analgesic Paracetamol drips $500 \mathrm{mg} / 8$ hours/IV, and Dexamethasone amp $5 \mathrm{mg} / 8$ hours / IV, and consulting the pulmonology department, internist, nutrition, and anesthesia department for surgery preparation.

Incision and drainage of the abscess were carried out at that time by observing the health protocol using PPE level 3. The patient was in a supine position, under general anesthesia Total Intravenous Anesthesia (TIVA), disinfection of the operating area, incision of the operating area using a blade 11 , then performed a blunt dissection to explore the abscess area, and finally installed a rubber drain figure 4. Surgery was carried out quickly to prevent cross-contamination between the patient and medical personnel in the operating room.

After incision and drainage of the abscess, the patient general condition changed with vital signs within normal limits, but oxygen saturation did not change by $94 \%$ (simple mask $5 \mathrm{lpm}$ ). The day after the patient was confirmed positive of Covid-19, the medical team involved in the operation conducted a Sars Cov-2 virological test using the PCR method to confirm the presence of Covid-19 infection from patient to medical personnel. The result was that all medical personnel involved in the operation were confirmed negative.

\section{Discussion}

This case report shows that a confirmed covid-19 patient with odontogenic infection was subjected to incision and drainage of the abscess with a protocol to prevent the spread of infection from patient to medical personnel. Surgical management of abscess patients must be well understood. The risk, if not treated properly, can lead to complications that can endanger the patient life. ${ }^{15}$ This condition is potentially more serious, because it can cause sepsis, and airway obstruction. ${ }^{16}$ Management and treatment of odontogenic infections of the maxillofacial area remains important in the practice of oral and maxillofacial surgery. ${ }^{17}$ 
The submandibular space is the most common location of odontogenic abscesses. ${ }^{18}$ Extension of the infection to adjacent fascial spaces develop in more than $50 \%$ of cases. ${ }^{18,19}$ Without proper and adequate treatment, the infection can spread along fascial planes caudally to the skull base, and in a rostral direction down to the mediastinum. ${ }^{20}$

Severe acute respiratory syndrome coronavirus 2 (SARS-CoV-2) is the cause of the 2019 coronavirus disease (Covid-19) and spreads rapidly around the world. ${ }^{21}$ The high mortality rate transmission pose a significant threat to global public health. ${ }^{22}$ WHO and other organizations have developed general guidelines to prevent such spread such as close contact with people who have respiratory infections, keeping the distance, hand washing especially after contacting with the contaminants or the contaminated environment, and using PPE to avoid the spread of pathogens. ${ }^{23}$

The management of surgical preparation for patients amid the Covid-19 pandemic must be adjusted to effectively manage patients with different conditions. For now, preoperative assessment should focus on detection of Covid-19 infection, stage of disease, and type of surgery (emergency, elective, or selective). ${ }^{24}$ At the early stage of the pandemic, the American College of Surgeons (ACS) recommended delaying surgery that was not considerably urgent. The level of risk of surgical patients should be evaluated before or immediately after admission to hospital. ${ }^{25}$

screening Covid-19 must be carried out by paying attention to clinical symptoms, physical examination, lab examination, chest-X Ray, and Rapid test antibody. This is in accordance with some literature in several countries for the stages of examining Covid-19.,11-14 There were found some indications leading to Covid-19 regarding the clinical symptoms, physical examination and blood culture in the patient. Accordingly, the SARSCoV-2 virological test was carried out, although the result came out one day after the patient was given treatment. ${ }^{7,11-14}$

Treatment of odontogenic infections is based on important elements, such as administration of special antibiotics and surgical intervention. ${ }^{26}$ Ideally, the antibiotics given should be in accordance with the results of culture and resistance tests, because this examination requires a long time, so the administration of antibiotics can be empirically based or according to the germ pattern in the area. ${ }^{16}$ This patient was given empiric intravenous antibiotic therapy with Ceftriaxone $2 x 1 \mathrm{gr}$ and metronidazole $3 \times 500 \mathrm{mg}$. This is linear to the study conducted by Shih-Wei Yang et al, where the use of the antibiotic combination Ceftriaxone and
Metronidazole had a significant effect improving the condition of patients with abscess due to odontogenic infections. Both of these antibiotics are sensitive to aerobic and anaerobic bacteria. ${ }^{27}$

Surgery was carried out even with the suspicion that the patient was indicated to have been exposed to covid-19 considering the emergency and the urgency for an immediate action. This is following the recommendation of the American College of Surgeons, that for surgical emergencies during this pandemic, patients who are known to be positive or have high clinical suspicion for Covid-19 infection, if possible and safe for patients, postponement of surgery can be done. However, if surgery is strongly required on the patient, appropriate PPE should be used to protect the medical surgical team. ${ }^{25}$ The medical team must select personal protection equipment that is proper to the risk of exposure. 28,29 The use of personal protective equipment must be adequately selected and used appropriately. Personal protective equipment should be chosen depending on the planned procedure and the patient's infection status. ${ }^{4,711-14}$

Incision and Drainage, and extraction of the tooth as the source of infection were performed in the patient. It is consistent with the belief that surgical management is based on two principles: elimination of the infectious focus and dissection of the disturbed space along with maximum drainage. Incision and drainage management must be carried out aggressively and promptly. This approach is based on the concept that maximum discharge of pus prevents the spread of infection to deeper spaces. ${ }^{16}$

In this case, the operating room used was still using a room with positive pressure, so that at the time of the action there were restrictions on medical personnel who were in the operating room. This is not consistent with the recommendations of several countries regarding the use of room negative pressure. ${ }^{711-14}$

Incision and drainage in abscess patients can still be done, even though the patient is confirmed COVID-19 by adhering to the principle of preventing the spread of covid-19. The general condition of the patient after the procedure had changed with vital signs within normal limits, but oxygen saturation was still the same. All of the SARS-CoV2 virological test results using the PCR method on the medical team were all confirmed negative.

\section{Conclusion}

Emergency services have undergone some changes. It is now important to prevent and control the spread of Covid-19, including protocols for surgical 
patient care and the safety of surgical teams. Even though they are not at the forefront, health workers who work in the operating room have a high risk of contracting Covid-19, especially during the operation. Surgical preparation, appropriate therapeutic management, and proper use of PPE will help provide the best service to patients while protecting medical personnel in the current Covid-19 pandemic era.

\section{Acknowledgment}

Thank you for Dental Hospital and Faculty of Dentistry Hasanuddin University for the support that has been given.

\section{Conflict of Interest}

The authors report no conflict of interest.

\section{References}

1. Kim J-K, Lee J-H. Clinical utility of procalcitonin in severe odontogenic maxillofacial infection. Maxillofac Plastic Reconstr Surg 2021;43;242.

2. Keswani ES, Venkateshwar G. Odontogenic maxillofacial space infections: a 5-year retrospective review in Navi Mumbai. J Maxillofac Oral Surg 2019;18: 345- 353.

3. Katoumas $\mathrm{K}$, Anterriotis D, Fyrgiola $\mathrm{M}$, et al. Epidemiological analysis of management of severe odontogenic infections before referral to the emergency department. J Cranio- Maxillofac Surg 2019;47: 1292- 1299.

4. Zimmermann M, Nkenke E. Approaches to the management of patients in oral and maxillofacial surgery during COVID-19 pandemic. J Cranio-Maxillofac Surg 2020;48: 521- 526

5. Wetan NGAAMY, Novianti PA. Surgical strategies in the Era of the COVID- 19 Pandemic. JBN 2020;4: 11.

6. Tobias JD. Preoperative anesthesia evaluation. Semin Pediatr Surg. 2018;27: 67- 74.

7. Barca I, Cordaro R, Kallaverja E, et al. Management in oral and maxillofacial surgery during the COVID- 19 pandemic: Our experience. Br J Oral Maxillofac Surg 2020;58: 687- 691.

8. Blackhall KK, Downie IP, Ramchandani P, et al. Provision of emergency maxillofacial service during the COVID-19 pandemic: a collaborative five centre UK Study. Br J Oral Maxillofac Surg 2020;58: 698- 703.

9. Dexter F, Parra MC, Brown JR, et al. Perioperative COVID-19 defense: an evidence-based approach for optimization of infection control and operating room management. Anesth Analg 2020;131: 37- 42.

10. Wong J, Goh QY, Tan Z, et al. Preparing for a COVID-19 pandemic: a review of operating room outbreak response measures in a large tertiary hospital in Singapore. Can J Anesth 2020;67: 732- 745.

11. Sohal KS, Simon ENM, Kalyanyama B, et al. Oral and maxillofacial surgical services amid COVID- 19 pandemic: perspective from Tanzania. Trop Med Health 2020;48: 1014.
12. Jiang L, Ma H. Surgical protocol in a West China day surgery center during the COVID-19 Pandemic: Practice and experience. Surg Innov 2020;37: 1- 5.

13. Panesar K, Dodson T, Lynch J, et al. Evolution of COVID-19 guidelines for University of Washington Oral and Maxillofacial Surgery patient care. J Oral Maxillofac Surg 2020;78: 1136- 1146 .

14. Coimbra R, Edwards S, Kurihara H, et al. European Society of Trauma and Emergency Surgery (ESTES) recommendations for trauma and emergency surgery preparation during times of COVID-19 infection. Eur J Trauma Emerg Surg 2020;46: 505- 510.

15. Bertossi D, Barone A, Iurlaro A, et al. Odontogenic orofacial infections. J Craniofac Surg 2017;28: 197- 202.

16. Guzmán-Letelier M, Crisosto-Jara C, Diaz-Ricouz C, et al. Severe odontogenic infection: An emergency. Case report. J Clin Exp Dent 2017;9: e319- e324.

17. Taub D, Yampolsky A, Diecidue R, et al. Controversies in the management of oral and maxillofacial infections. Oral Maxillofac Surg Clin North Am 2017;29: 465- 473.

18. Hemalatha VT, Manigandan T, Sarumathi T, et al. Dental considerations in pregnancy-A critical review on the oral care. J Clin Diagnostic Res 2013;7: 948- 953.

19. Steinberg BJ, Hilton IV, Iada $\mathrm{H}$, et al. Oral health and dental care during pregnancy. Dent Clin North Am 2013;57: 195-210.

20. Dalla Torre D, Burtscher D, Höfer D, et al. Odontogenic deep neck space infection as life-threatening condition in pregnancy. Aust Dent J 2014;59: 375- 378.

21. Yüce M, Filiztekin E, Özkaya KG. COVID-19 diagnosis: A review of current methods. Biosens Bioelectron 2021;172: 112752.

22. Liu X, Liu C, Liu G, et al. COVID-19: Progress in diagnostics, therapy and vaccination. Theranostics 2020;10: 7821- 7835 .

23. Amawi H, Abu-Deiab GI, Aljabali AA, et al. COVID-19 pandemic: An overview of epidemiology, pathogenesis, diagnostics and potential vaccines and therapeutics. Ther Deliv 2020;11: 245- 268

24. Wang L, Lu X, Zhang J, et al. Strategies for perioperative management of general surgery in the post-COVID-19 era: experiences and recommendations from frontline surgeons in Wuhan. Br J Surg 2020;107: e437.

25. Kumar J, Raina R. Recommendations for surgery during the COVID- 19 pandemic. Indian J Surg 2020;82: 297- 298.

26. Sebastian A, Antony PG, Jose M, et al. Institutional microbial analysis of odontogenic infections and their empirical antibiotic sensitivity. J Oral Biol Craniofacial Res 2019;9: 133- 138.

27. Yang SW, Lee MH, See LC, et al. Deep neck abscess: an analysis of microbial etiology and the effectiveness of antibiotics. Infect Drug Resist. 2008;1: 1- 8.

28. Zhao Z, Gao D. Precaution of 2019 novel coronavirus infection in department of oral and maxillofacial surgery. Br J Oral Maxillofac Surg 2020;58: 250- 253.

29. Chanda MH. Canina fossa abscess and treatment. J Dentomaxillofac Sci 2018;3: 54-57.

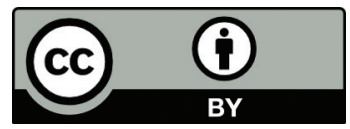

This work is licensed under a Creative Commons Attribution 